\title{
Research on the Key Restrictive Factors of Green Energy Industry Development in Western China
}

\author{
Chenglei Xu, Tongjie Chen*, and Yonghe Sun \\ Kunming University of Science and Technology, 650000 Kunming, China
}

\begin{abstract}
The development of the green energy industry in western China plays an important role in promoting local economic and social development and ensuring national energy security. At the same time, industrial development also faces imbalances in the supply and demand of green energy, insufficient local energy consumption, limited extension of the industrial chain, poverty alleviation and ecological protection and other issues. Combining the development characteristics of the green energy industry in the western region, with policy guidance, market improvement, and technological progress as the main analysis framework, based on the Delphi method, the key constraints for the green energy industry in western China are proposed, and the western green energy industry and social economy. The possible mechanism of action between development has certain reference value for promoting the development of the green energy industry and improving the operation mechanism of the green energy industry.
\end{abstract}

\section{Introduction}

In the context of the global energy transition, China, as a major energy producer and consumer, has continued to advance the energy revolution process. The western region plays a pivotal role in China's energy strategy. Therefore, exploring the key limiting factors for the development of the green energy industry in western China is an important strategic layout for the development of China's energy industry, and it is also a key core for promoting the development of the local economy by the green energy industry in the western region [1].

The western green energy industry has effectively boosted local economic development and promoted the construction of poverty alleviation projects [2]. At present, China's central and eastern regions have begun to transition to a high proportion of energy selfsufficiency [3], and their dependence on energy in the western region has declined. At the same time, energyintensive industries began to shift to the western region, and local energy demand also increased. Therefore, the development of the green energy industry in the western region is of great significance for ensuring national energy security and balancing energy supply and demand. The existing literature on the research on the restrictive factors of the green energy industry focuses on the impact of energy characteristics, policy systems and technical levels on industrial development [4-5], lack of comprehensive thinking on the development of the western green energy industry, the mechanism of action of various factors on the energy industry is not yet clear. Based on the above considerations, this article is based on the characteristics of the resource endowment in the western region and the actual economic and social development, combined with relevant documents to propose an analysis framework for key constraints in the western region, and uses the Delphi method to identify the key factors, so as to obtain the relevant key factors for the western green energy industry Influence path of development.

\section{Analysis on the development characteristics of green energy industry in Western China}

The western region of China has obvious advantages in green energy endowment, but it also has the characteristics of unstable green energy supply and demand balance, insufficient local energy consumption, limited extension of the industrial chain, imperfect poverty alleviation and ecological protection mechanisms, as follows:

\subsection{Energy supply and demand imbalance}

Affected by factors such as seasonal drought and insufficient ecological compensation mechanism [6], the current progress of green energy development in the western region is limited, and the total energy growth is slow. As shown in Figure 1, the power generation of many provinces is still below the national average. In contrast to the slow growth of energy supply, the demand for green energy production capacity is constantly increasing. On the one hand, large coal power stations have been shut down in response to the policy call for low-carbon and environmental protection; on the

\footnotetext{
*Corresponding author: a951548328@vip.qq.com
} 
other hand, the western economic development policyoriented call for consumption The accumulation of energy industries in the west has led to an increasing gap in the balance of supply and demand, and increased industrial operating risks.

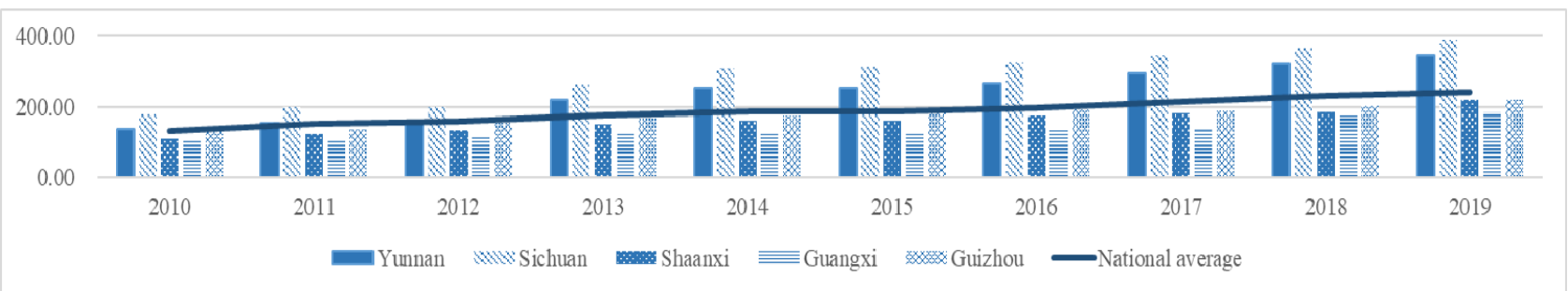

Fig. 1. Comparison of power generation growth trends in Western China in recent ten years (unit: 1 billion KWH)

\subsection{Insufficient local consumption}

From the perspective of overall energy consumption, the overall energy consumption level in the western region is relatively low. As shown in Figure 2, even with the gradual commissioning of large-scale energy-carrying industries in recent years, the energy consumption levels of many provinces are below the national average consumption level. With the negative effects of the high base and low incoming water in the central and eastern regions, the energy demand for the western regions is showing a downward trend. At present, in order to promote local energy consumption in the western region, energy-consuming industries continue to gather in the western region, but the seasonal "surplus and shortage" of green energy has led to the randomness and volatility of energy output and increased market operation risks. Therefore, while promoting the expansion of the green energy industry in the western region, ensuring the stability of energy supply is the core of the current energy industry development.

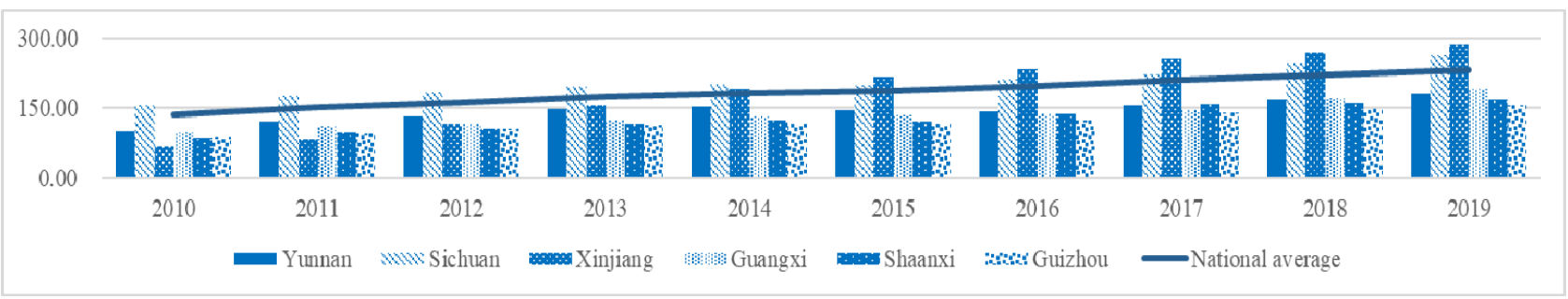

Fig. 2. Comparison of growth trend of total power consumption in Western China in recent ten years (unit: 1 billion KWH)

\subsection{Limited extension of industrial chain}

The extension of the green energy industrial chain in western China is relatively limited, and the integration of energy development and related industry development is relatively poor in breadth and depth. The secondary and multiple conversions of electricity have not been effectively realized, resulting in green energy advantages that have not been effectively transformed into economic advantages. The promotion of other industries is limited. The current green energy industry chain is still dominated by power generation and transmission. The advantage of surplus power in the abundant resource period has not been converted into resource advantage. High value-added products such as electrolytic aluminum, electrolytic silicon, new energy vehicles, energy big data, energy finance, etc. The downstream industry chain is not deep enough, and there are still many difficulties and challenges in the expectation of relying on green energy to stimulate economic and social development and change the public's production and lifestyle.

\subsection{Incomplete poverty alleviation and ecological protection mechanisms}

The western region is rich in ecological resources and fragile in ecological environment. Most of the energy rich areas are located in economically underdeveloped poverty-stricken areas, resulting in the disharmony of energy rich but poor. It is inevitable to consider a series of problems such as ecological compensation and poverty alleviation in the development of green energy industry to ensure the balance and unity of ecological and economic benefits. The poverty alleviation projects supported by energy enterprises and poverty alleviation projects mainly based on distributed photovoltaic have achieved remarkable results, but they have also increased the business burden of enterprises [8]. The project ecological exclusion and ecological compensation mechanism also lead to the slow progress of energy development and construction, which has a lot of adverse effects on promoting the construction of green energy industry in Western China and expanding green production capacity.

\section{Analysis framework of key constraints on the development of green energy industry in Western China}


The existing restrictive factors for the development of green energy industry focus on promoting the large-scale development of green energy and promoting green energy consumption, but less consideration is given to ensuring the supply stability of green energy. This paper is based on Yuan J [7] and Dincer I [8] used the influencing factor model of energy industry development and improved it from three aspects of policy guidance, market improvement and technological progress, and proposed the analysis framework as shown in Table 1

Table 1. Analysis framework of green energy industry constraints

\begin{tabular}{|c|c|c|}
\hline First level index & Second level index & Index meaning \\
\hline \multirow{4}{*}{ A1 Policy guidance } & B1 National goal policy & Timeliness, scientific, consistency \\
\hline & B2 Policy adaptation & $\begin{array}{l}\text { The adaptation of policy and economic development, the coordination of } \\
\text { central government and local government, the adaptation of development } \\
\text { policy and environment }\end{array}$ \\
\hline & B3 Economic policy & Financial subsidies, tax incentives, low interest loans, price concessions \\
\hline & $\begin{array}{l}\text { B4 Government } \\
\text { regulatory policies }\end{array}$ & $\begin{array}{l}\text { Integrated management and sub-departmental management system, } \\
\text { authenticity audit system }\end{array}$ \\
\hline \multirow{4}{*}{$\begin{array}{l}\text { A2 Market } \\
\text { improvement }\end{array}$} & $\begin{array}{l}\text { B5 Power generation } \\
\text { side }\end{array}$ & $\begin{array}{l}\text { Unit generation cost, market quotation, market supply level, technical } \\
\text { efficiency }\end{array}$ \\
\hline & B6 Power supply side & $\begin{array}{l}\text { Power supply market structure, transmission and distribution voltage level } \\
\text { structure, electricity charge recovery rate. }\end{array}$ \\
\hline & B7 Electricity trading & $\begin{array}{l}\text { Stability of market supply and demand and electricity price, market risk, } \\
\text { transaction rules }\end{array}$ \\
\hline & $\begin{array}{l}\text { B8 Coordinated } \\
\text { development }\end{array}$ & $\begin{array}{l}\text { Electricity elasticity coefficient (coordination of power and economic } \\
\text { development), coordination of power supply and grid planning, investment } \\
\text { ratio of power transmission and distribution }\end{array}$ \\
\hline \multirow{3}{*}{$\begin{array}{l}\text { A3 Industrial } \\
\text { application }\end{array}$} & B9 Technical support & Technological innovation, talent development [9] \\
\hline & B10 Application basis & Exploitable energy, investment level, infrastructure equipment [10] \\
\hline & $\begin{array}{l}\text { B11 Market } \\
\text { environment }\end{array}$ & Market environment, market demand, market competition \\
\hline
\end{tabular}

\section{Identification of key factors based on Delphi method}

Based on the above analysis and framework setting, with the help of Delphi method, 32 industry experts who have been engaged in energy industry research for more than
10 years from China Power Construction Group, China Southern Power Grid, Electric power design institute, Energy Research Institute and Yunnan Energy Bureau were introduced as members of the expert advisory group to score and evaluate the relevant factors. The specific results are shown in Table 2.

Table 2. The results of the first and second round of opinions on the constraints of green energy industry

\begin{tabular}{|c|c|c|c|c|c|c|}
\hline \multirow{2}{*}{$\begin{array}{l}\text { First level } \\
\text { index }\end{array}$} & \multirow{2}{*}{$\begin{array}{c}\text { Second } \\
\text { level } \\
\text { index }\end{array}$} & \multirow[b]{2}{*}{ Third level index } & \multicolumn{2}{|c|}{$\begin{array}{l}\text { First round } \\
\text { consultation }\end{array}$} & \multicolumn{2}{|c|}{$\begin{array}{c}\text { Second round } \\
\text { consultation }\end{array}$} \\
\hline & & & Average & $\begin{array}{l}\text { Full Score } \\
\text { frequency }\end{array}$ & Average & $\begin{array}{c}\text { Full } \\
\text { Score } \\
\text { frequency }\end{array}$ \\
\hline \multirow{12}{*}{ A1 } & \multirow{3}{*}{ B1 } & P1 Policy timeliness & 8.13 & 0.41 & 8.24 & 0.41 \\
\hline & & P2 Scientific policy & 8.32 & 0.44 & 8.56 & 0.5 \\
\hline & & P3 Policy consistency & 8.26 & 0.47 & 8.30 & 0.47 \\
\hline & \multirow{3}{*}{ B2 } & P4 Economic adaptability & 8.21 & 0.44 & 8.37 & 0.44 \\
\hline & & P5 Regional adaptability & 8.66 & 0.5 & 8.76 & 0.53 \\
\hline & & P6 Environmental adaptability & 8.23 & 0.44 & 8.3 & 0.44 \\
\hline & \multirow{4}{*}{ B3 } & P7 Financial subsidies & 8.46 & 0.47 & 8.47 & 0.47 \\
\hline & & P8 Tax preference & 7.98 & 0.31 & 8.17 & 0.31 \\
\hline & & P9 Low interest loans & 7.64 & 0.25 & 7.65 & 0.28 \\
\hline & & P10 Price concessions & 8.01 & 0.38 & 8.17 & 0.38 \\
\hline & \multirow{2}{*}{ B4 } & $\begin{array}{l}\text { P11 Integrated management and sub- } \\
\text { departmental management system* }\end{array}$ & 8.48 & 0.5 & 8.42 & 0.5 \\
\hline & & P12 Authenticity audit system & 6.89 & 0.03 & - & - \\
\hline \multirow{6}{*}{$\mathrm{A} 2$} & \multirow{4}{*}{ B5 } & P13 Unit generation cost & 8.22 & 0.41 & 8.13 & 0.38 \\
\hline & & P14 Market quotation & 7.96 & 0.34 & 8.07 & 0.34 \\
\hline & & P15 Market supply level & 8.01 & 0.34 & 7.9 & 0.31 \\
\hline & & P16 Technical efficiency & 8.22 & 0.47 & 8.16 & 0.44 \\
\hline & \multirow{2}{*}{ B6 } & P17 Power supply market structure & 7.96 & 0.31 & 8.01 & 0.31 \\
\hline & & P18 Transmission and distribution voltage & 7.86 & 0.28 & 7.63 & 0.25 \\
\hline
\end{tabular}




\begin{tabular}{|c|c|c|c|c|c|c|}
\hline & & grade structure & & & & \\
\hline & & P19 Electricity charge recovery rate & 6.98 & 0.13 & - & - \\
\hline & \multirow{3}{*}{ B7 } & $\begin{array}{l}\text { P20 Stability of market supply and } \\
\text { demand and electricity price }\end{array}$ & 8.58 & 0.53 & 8.69 & 0.53 \\
\hline & & P21 Market risk & 8.24 & 0.41 & 8.27 & 0.41 \\
\hline & & P22 Transaction rules & 8.02 & 0.38 & 8.07 & 0.38 \\
\hline & \multirow{3}{*}{ B8 } & P23 Electric elasticity coefficient & 8.07 & 0.34 & 8.26 & 0.34 \\
\hline & & $\begin{array}{l}\text { P24 Coordination of power supply and } \\
\text { grid planning }\end{array}$ & 8.63 & 0.5 & 8.69 & 0.5 \\
\hline & & $\begin{array}{l}\text { P25 Investment ratio of power } \\
\text { transmission and distribution }\end{array}$ & 7.94 & 0.31 & 8.01 & 0.31 \\
\hline \multirow{8}{*}{ A3 } & \multirow{2}{*}{ B9 } & P26 Technology innovation & 8.36 & 0.41 & 8.40 & 0.44 \\
\hline & & P27 Talent development & 8.19 & 0.41 & 8.26 & 0.41 \\
\hline & & P28 Exploitable energy & 8.02 & 0.34 & 8.06 & 0.38 \\
\hline & $\mathrm{B} 10$ & P29 Investment level & 8.06 & 0.38 & 8.04 & 0.38 \\
\hline & & P30 Infrastructure equipment & 8.21 & 0.41 & 8.17 & 0.41 \\
\hline & & P31 Market environment & 8.02 & 0.38 & 8.11 & 0.38 \\
\hline & B11 & P32 Market demand & 8.43 & 0.47 & 8.42 & 0.44 \\
\hline & & P33 Market competition & 8.17 & 0.41 & 8.12 & 0.41 \\
\hline
\end{tabular}

* In the second round of consultation, it was changed to "multi-departmental management policy adaptation" and classified into B2; underlined and italicized fonts indicate factors that were deleted in the second round of consultations after comprehensive evaluation based on expert opinions; bold fonts indicate factors with higher mean scores in the second round of consultation.

The results of the two rounds of consultation show that the development of the green energy industry in the western region is comprehensively affected by various factors such as policy orientation, power structure, and technological level. Among them: formulating scientific development policies that match the local economic development according to the local infrastructure environment and promoting the adaptation of multisectoral energy management policies are the foundation for the development of the western green energy industry. The balance of market supply and demand and stable electricity prices, and the coordination of power supply and grid planning are the guarantee for the stable and sustainable development of the western green energy industry. Innovation of key technologies such as energy storage, grid connection, peak shaving, and promotion of the improvement of the industrial chain to expand market demand are the main driving forces for the development of the western green energy industry. Promoting poverty alleviation and ecological compensation during the energy construction period through government and enterprise support is a necessary consideration for the western green energy industry. Promoting the construction of the entire industrial chain with industrial development, thereby promoting social and economic development, and realizing the national energy security strategy is the ultimate goal of green energy development in the western region.

\section{Conclusion}

In response to the actual needs of the development of the green energy industry in the western region, the development characteristics and key constraints of the green energy industry in the western region are systematically condensed, and the potential mechanism of the relevant factors on the development of the green energy industry in the western region is proposed. It provides a useful reference for the green energy industry in the western region to ensure stable energy supply and improve the energy development mechanism. It has certain theoretical research significance and practical exploration value for green energy industry to promote local social and economic development, promote energy structure adjustment and industrial chain expansion.

\section{Acknowledgement}

Thanks to the Chinese Academy of Engineering's "Yunnan Green Energy Industry Sustainable Development Strategic Consulting Research" (2020YNZH3) and the Yunnan Provincial Academy of Education Cooperation Humanities and Social Science Research Key Project "Yunnan Green Energy Industry Development Mechanism and Policy Research" for the foundation strong support for this topic.

\section{References}

1. P.S. Reddy, S. Avik, D. Eyup. Environmental Science and Pollution Research International, 24 (2017)

2. B. Lin, M. Moubarak. Renewable \& Sustainable Energy Reviews, 40 (2014)

3. H. Bloch, S. Rafiq, R. Salim. Economic Modelling, 44 (2015)

4. Kumar, Abhishek, Sah, Bikash, Singh, R. Arvind, et al. Renewable \& Sustainable Energy Reviews, 69 (2017)

5. Mundaca L, Neij L, Markandya A, et al. Applied Energy, 179 (2016)

6. Lund, D. Peter. International Journal of Energy Research, 40 (2016) 
7. J. Yuan, Y. Xu, X. Zhang, et al. Energy Policy, 65 (2014)

8. Dincer I, Acar C. International Journal of Energy Research, 39 (2015)

9. Yan J, Chou S K, Applied Energy, 162 (2015)

10. Jones A W. Journal of Cleaner Production, 104 (2015) 